\title{
Debatartikel
}

\section{Er jeg min broders vogter?}

\author{
Et socialdemokratisk anslag mod demokratiet - en case \\ Af Jørn Helder *)
}

\begin{abstract}
Resumé
I denne artikel tages Samfundslederskab bogstaveligt, idet det er Socialdemokratiet, der her er i centrum. Artiklen tager udgangspunkt i to forskellige cases, som begge har betydelige fællestræk i forhold til at vogte om demokratiet og den demokratiske dialog. Hovedtemaerne er Socialdemokratiets gradbøjning af demokratiet i perspektiv af deres magtfuldkommenhed, deres tillidsbrud, deres uetiske adfærd og en selvfremstilling, der efterlader en med spørgsmålet om, hvem de egentlig er - eller ønsker at være.
\end{abstract}

*) Jørn Helder er cand.mag., ph.d. og ekstern lektor. 


\section{A. Indledning}

Overskriften refererer til Det Gamle Testamentes beretning om Kains mord på hans broder Abel. Efter at han har dræbt sin broder, spørger Gud Kain, hvor hans bror er, hvortil Kain svarer Jeg ved det ikke. Er jeg min broders vogter?

Beretningen kan forstås som en fortælling om ansvar - i dette tilfælde Kains ansvar for broderen, men i et bredere perspektiv generelt om et ansvar for andre mennesker. Kain demonstrerer med sit svar, at han ikke føler dette ansvar. Appliceret på den aktuelle politiske situation føler Socialdemokratiet sig tilsyneladende heller ikke som sin broders vogter i forhold til sikring af vort demokrati - heller ikke til trods for den tsunami af commisive talehandlinger, der er indeholdt i diverse socialdemokratiske udmeldinger, fx åbningstalen oktober 2019, partiets principprogram mv. I stedet udfylder partiet fint rollen som den politiske Kain, der lidt fornærmet spørger, om han er sin broders vogter - altså er nødt til at påtage sig ansvar for andre. At nogen oplever sig som sin broders vogter, betyder at man påtager sig et ansvar for andre mennesker - på baggrund af de her nævnte cases og fx deres partiprogram tilsyneladende et luksusdilemma for et Socialdemokrati, der nærmest med perfektion synes at spille rollen som vogter i forhold til demokratiet og dermed ifølge Kierkegaard eksponerer sit falske selv.

Et centralt tema hos Kirkegaard er identiteten og selvet, som han bl.a. behandler i sine psykologiske hovedværker "Gjentagelsen”, "Begrebet Angest” og "Sygdommen til døden”. I "Begrebet Angest" forklarer han ved hjælp af skabelsesmyten, hvorfor og hvordan mennesket har mistet sin identitet i Paradisets Have. Her var mennesket bestemt som et biologisk væsen, var helt og usplittet (og uskyldigt). Men ordet i form af forbuddet fremkalder fristelsen til at spise af kundskabens træ, dvs. skaffe sig viden, hvorved mennesket blev sig selv bevidst. Og efterfølgende blev uddrevet af Paradiset.

Efter uddrivelsen var mennesket således ikke længere kun et biologisk, men også et åndeligt væsen. Ånd er bevidstheden om sig selv i forhold til medmennesket og i forhold til tiden. Ånd bliver også bevidsthed om sig selv i forhold til liv og død og meningen med tilværelsen. Et menneske, der ikke har selv-bevidsthed, kalder Kierkegaard for åndløst, og det åndløse menneske søger sin identitet i kollektivet, men "kollektivet er som en sildestime - den enkelte er ikke en sild værd".

Eller også søges identiteten ifølge Kierkegaard i det udvortes, det vil sige i de forskellige roller, man går ind i og spiller. En rolle er ifølge Kierkegaard forbundet med en vis tilfredsstillelse, fordi den gør det muligt at realisere både det almene og det individuelle. Men man bliver offer for selvbedrag, og bedrageren er det falske selv, dvs. det selvbillede eller selvillusion, man har opbygget for at finde sin identitet. Forsøger man så at trænge ind bag rollerne og det falske selv for at finde sin identitet, 
opdager man, at der ikke er noget ud over tomheden. Et karakteristikum ved selvbedraget er ifølge Kierkegaard, at (selv)bedrageren altid vil blive afsløret. Den eneste mulighed er valget, som står helt centralt hos Kierkegaard, nemlig at vælge sig selv og identificere sig med de roller man er - ikke spiller, hvilket i høj grad også gælder for Socialdemokratiet. Kort sagt et spørgsmål om autenti vs. ikke-autenti.

\section{B. Mail-gate}

Søndag den 23. februar 2020 kunne Jyllands Posten i en artikel referere til en mail, som avisen havde modtaget angiveligt ved en fejltagelse. Artiklen beskrev en mail, der indeholdt en detaljeret socialdemokratisk plan for, hvordan man ville angribe og kompromittere Venstre under og efter forhandlinger om udligningsreformen ved at referere til temaer, som havde været forhandlet "under rosen" - altså i absolut fortrolighed.

Planen er orkestreret af Finansministerens personlige rådgiver, der ifølge Jyllands Postens referat "[...] skal finde »historier på Venstre (...) på baggrund af svar fra forhandlinger og andet «. Mailen er sendt fra Socialdemokratiets politik- og presseafdeling til medarbejdere i afdelingen, særlige rådgivere i både Social-, Indenrigs- og Finansministeriet og flere af partiets politikere. Således er fx Lea Wermelin, Benny Engelbrecht, Trine Bramsen eksplicit nævnt og skal bl.a. deltage i "læsemøder" - hvad det så end er? Måske for at de kan lære at læse og formidle budskaberne på "socialdemokratisk"? At det er en pædagogisk øvelse i forhold til de enkelte deltagere i angrebet, dokumenteres senere i mailen, hvor man for at sikre det fælles socialdemokratiske sprog og fælles fodslag skriver, at der også skal indgå Håndholdt info til MF'ere som taber på udligning. Men det kunne jo også vise sig at være ganske risikabelt at overlade ethvert individuelt initiativ og selvstændig tænkning til det enkelte medlem.

At man ikke går på listefødder eller er specielt sensibel i valget af terminologi, dokumenterer et udtryk som "angreb", der gentages flere gange i mailen, og som sådan lancerer en krigsdiskurs. (For uddybning af diskurs se afsnit 5). Dette er oprustning. Bemærkelsesværdigt er det naturligvis, at Statsministeriet nævnes først i interessentgruppen af ministerier og derfor må antages at spille en ikke uvæsentlig rolle - uagtet at formand for Socialdemokratiet og statsminister Mette Frederiksen i Folketingssalen efterfølgende lagde afstand til indholdet af mailen, som i uddrag citeres her:

\section{Tovholder på de forskellige opgaver i AIA}

Kim:

- Koordinering mellem AIA og STM, FM og SIM

- Liste over historier om udligning 
Kim og Claus:

- Historier på Venstre i samarbejde med Mathias Secher pba. svar fra forhandlinger og andet.

Mads:

- Angreb fra Christian og Jesper (og evt. andre fra DPH-udligningsgruppen) i medier og på SoMe

- Indlæg fra ministre i lokale og regionale medier

At mailen/planen både i form og indhold fremstår dilettantisk, skal her blot nævnes som et kuriosum, men under alle omstændigheder ikke noget, der er egnet til at skabe tillid til forfatteren af planens faglighed i forhold til at forestå nogen form for kommunikationsplanlægning. Endsige til de aktører, der er udpeget til at deltage i det socialdemokratiske dukketeater. Men at mailen overhovedet er skrevet i relation til en forhandlingssituation, hvor tillid er altafgørende, udgør et massivt problem. Dette får dog ikke den socialdemokratiske finansordfører, Christian Rabjerg, til at ryste på hånden. Han mener - forankret i sit socialdemokratiske Fantasia - ikke tilliden i forhandlingslokalet er brudt. Man kan således ikke klandre Rabjerg for at være jordnær, men måske blot et udtryk for den monopolisering af statsapparatet og den magtfuldkommenhed, som Thuelsen Dahl (DF) er citeret for i Jyllands Posten (23. februar 2020), hvor han siger, at opførslen fra S vidner om, »en et-partiregering, der har sat sig på statsapparatet og misbruger det i egen partiinteresse”. Som sådan adresserer Thuelsen Dahl et problem, der rækker temmelig meget videre end den aktuelle mail - også selv om tillidsbrud i relation til en demokratisk dialog synes tilstrækkelig alvorligt. Det vil blive behandlet nedenfor.

Reaktionerne på den omtalte mail har været mange. Antageligt vil nogle mene i deres demokratiblaserthed, at reaktionerne er stor ståhej for ingenting, eller at det bare er sådan det politiske spil spilles. Men hvis man løfter blikket fra mail-gate og kigger bag facaden, er det uligt mere alvorlige sager, der er på spil her. Det er dog ikke specielt overraskende, at finansminister Wammen søndag den 23. februar 2020 i Berlingske Tidende karakteriserer sagen som "Christiansborg-fnidder" og på den måde forsøger at bagatellisere hele sagen. Mere overraskende er det (og måske alligevel ikke?), at også Det Radikale Venstres leder, Morten Østergaard, karakteriserer det som Christiansborg-fnidder, når han i Berlingske Tidende 24. februar er citeret for at sige:

Hvis statsministeren gør det samme [lægger sig fladt ned, JH], så vil jeg tro, at vi hurtigt kan komme i gang med forhandlingerne igen. Det vigtige er jo, at vi får lavet en god reform og ikke dette her Christiansborg-fnidder, siger Morten Østergaard. 
Så bliver det nemlig uforholdsmæssigt mere alvorligt, hvis politikere generelt ikke adresserer et sådant tillidsbrud med den nødvendige seriøsitet. Dette er nemlig ikke "fnidder", der i "sproget.dk" defineres som små personlige uoverensstemmelser og interne magtkampe, fx inden for politik; diskussion og uenighed om småting. Dette er ikke "småting", Det er tværtimod et alvorligt demokratisk problem, der ikke blot kan dekonstrueres og elimineres ved at italesætte det som "fnidder". Det handler nemlig grundlæggende om troværdighed, tillid og etik (læs: manglen på samme) her repræsenteret ved politikere, der åbenlyst enten negligerer hele det demokratiske rationale eller bevidst forsøger at bagatellisere de demokratiske processer som rene skuesprocesser - et forhold som den tyske sociolog Habermas har analyseret og beskrevet i sin afhandling "Den borgerlige offentlighed" (1962).

Mail-gate er desværre ikke enestående i forhold til de stadige bestræbelser på at neutralisere demokratiske processer og den demokratiske dialog. Og det skal hverken bagatelliseres eller forties. Det skal frem i lyset, ligesom de politikere, der vælges demokratisk, løbende skal holdes op på deres accept af og forsvar for demokratiet.

Mail-gate er nemlig langt fra et isoleret eksempel på Socialdemokratiets forsøg på at bemægtige sig og beherske en aktuel diskurs - og magten. En anden yderst illustrativ sag, der er kommet til at stå lidt i skyggen af mail-gate, er nemlig Socialdemokratiets forsøg på at problematisere forskellige kommentatorers og forskeres kritiske kommentarer til forskellige socialdemokratiske projekter og på den måde forsøge at monopolisere meningsdannelsen og diskursen i et forsøg på at konstruere en socialdemokratisk virkelighed, der skal omfatte alle. Og ve den, der ikke forstår eller lystrer! Denne magtfuldkommenhed skal naturligvis debatteres i forhold til både demokrati, demokratisk dialog, diskurs, kommunikation, tillid, etik og troværdighed.

\section{Diktat eller dialog det socialdemokratiske tankepoliti og demokratisk rollespil}

Mandag den 17. februar 2020 bragte Berlingske Tidende en artikel skrevet af journalist Helene Kristine Holst, hvor overskriften lød: Topfolk $i$ Socialdemokratiet har presset kritiske eksperter af partiets politik: »Jeg vil bare advare dig. Christiansborg kan voere en krigszone"

Artiklen nævner fire eksempler på, hvordan Socialdemokratiet gennem embedsmænd (ikke politikere, der kan holdes politisk ansvarlige) har forsøgt at styre og bemægtige sig diskursen og disciplinere den offentlige debat ved at intimidere forskellige aktører, der har stillet sig kritisk over for forskellige socialdemokratiske projekter. Det drejer sig ifølge artiklen b.la om Mellemfolkeligt Samvirke, Folkekirkens Nødhjælp, professor i Økonomistyring ved Aalborg Universitet Per Nikolaj Bukh og forsker med speciale i tunesiske forhold ph.d. Rikke Haugbølle. Alle aktørerne er blevet 
kontaktet af enten ansatte i den socialdemokratiske organisation eller ansatte i forskellige ministerier for at styre dem i en af Socialdemokratiet bestemt retning - ved at advare dem. Det turde her være unødvendigt at eksplicitere advarslens iboende trussel om sanktioner i forhold til ikke at disciplinere sig. Om dette forhold siger Roger Buch, forskningsleder ved Danmarks Medie- og Journalisthøjskole:

Det er problematisk, når et parti eller en regering kontakter kritikere, for i den store helhed kan det betyde, at for eksempel organisationer begynder at være bekymrede for konsekvensen, hvis de er kritiske over for magthaverne. (Berlingske Tidende, 17. februar 2020)

Det er et mildest talt et kolossalt demokratisk problem, når Socialdemokratiet på denne måde forsøger at kortslutte en kritisk, demokratisk debat. Her skal to af de nævnte eksempler foldes yderligere ud.

Det første eksempel drejer sig om et socialdemokratisk udlændingeudspil fra 2018, hvor partiet foreslog etablering af modtagecentre i udlandet. I den anledning blev Rikke Haugbølle, kontaktet af flere medier for en kommentar til det socialdemokratiske forslag. Hun nævnte, at forslaget i et større perspektiv ikke var nyt, da Frankrig tidligere havde lanceret et tilsvarende forslag, hvilket havde medført voldsom kritik fra menneskerettighedsorganisationer. Haugbølle havde udtrykt nogen forbløffelse over forslaget, idet hun dels syntes, det var mærkeligt at fremsætte et sådant forslag efter kritikken af Frankrig, dels havde svært ved at se, hvordan det skulle gennemføres rent praktisk. Efter en optræden i DR blev hun af en politisk konsulent indbudt til at komme ind på Christiansborg for at tale med socialdemokraterne om deres udspil. Kort efter ringede pressechefen, Mads Brandstrup (i dag særlig rådgiver for Nicolai Wammen), og advarede hende ifølge hendes egne notater:

Skal vi være enige om, at du udtaler dig om Nordafrika og ikke om Frankrig?« har hun noteret, at Mads Brandstrup sagde til hende med henvisning til, at hun ikke skulle udtale sig om, hvorvidt Frankrig havde skrinlagt ideen. [...] Jeg vil bare advare dig. Christiansborg kan være en krigszone, og det synes jeg bare, du skal vide, inden du bevæger dig derind. (Berlingske Tidende, 17. februar 2020)

Også den omtalte konsulent understregede efterfølgende, at Haugbølle ikke skulle mene noget om Frankrig, da de danske socialdemokrater havde tætte forbindelser til deres franske søsterparti. Efterfølgende har Mads Brandstrup ikke ønsket at kommentere sagen - ligesom ingen socialdemokratisk ansatte har villet kommentere på de andre sager omtalt i Berlingske Tidendes artikel. 
Den anden case, som skal omtales, drejer sig om økonomiprofessor Per Nikolaj Bukh, professor ved Aalborg Universitet. Han er nemlig også blevet hevet ind og har fungeret som lerdue i det socialdemokratiske skydetelt, bl.a. efter at have anfægtet påstande og argumenter på det, som Berlingske Tidendes artikel (17. februar 2020) karakteriserer "på afgørende politikområder", bl.a. i forbindelse med en diskussion om daværende minister (LA), Thyra Franks plejehjem. Dette resulterede i en kontakt fra Lynne Birch Hansen, som var politisk rådgiver i Socialdemokratiet og i dag er indenrigsminister Astrid Kraghs særlige rådgiver. Når man ser på galleriet af rådgivere i det socialdemokratiske embedsværk, kan iagttagere med ond vilje naturligvis associere de socialdemokratiske ansatte med Henrik Ibsens "Gengangere". Positivt anskuet sikrer partiet både arvefølgen og fælles fodslag i embedsværket og bevarer dermed kontinuiteten i partiets særlige gradbøjning af moral og etik. Et forhold, der blev yderligere understreget, da pressechefen i Finansministeriet, Sigga Noelsøe ifølge DR (4. marts 2020) forlod ministeriet med følgende salut: «- Jeg kan bare sige, at det er en svær stilling at have, hvis man ikke er professionel Socialdemokrat.»

Bukh kritiserede også partiets økonomiske 2025-plan, som skulle finansieres ved hjælp af skattestigninger, som dog ifølge partiet kun ville ramme fem procent af befolkningen, hvilket flere eksperter satte spørgsmålstegn ved. Dette udløste atter en tilnærmelsesvis pavlovsk reaktion fra Socialdemokratiet, der som Bukh selv er citeret for i artiklen (17. februar 2020) "ønskede ganske enkelt, at jeg havde en anden holdning.

Eksemplerne med Mellemfolkelig Samvirke og Folkekirkens Nødhjælp er legio.

Socialdemokratiet ønsker ved den uraffinerede magtudøvelse at disciplinere organisationer og eksperter til at ytre sig inden for den diskurs, Socialdemokratiet har italesat omkring forskellige tematikker.

Nogle vil måske mene, at den socialdemokratiske ageren ikke er noget at hidse sig op over endsige bekymre sig om, men hver eneste gang nogen slipper afsted med den type disciplinerende overgreb, der er beskrevet her, flyttes vores tolerancegrænse for, hvad der er acceptabelt og ikke acceptabelt en smule, hvilket naturligvis udgør en ikke ringe fare for vores demokratiske bevidsthed og demokratiske handlemuligheder. Og vi accepterer - bevidst eller ubevidst - en indskrænkning, der kan have store konsekvenser, som fx beskrevet af den britiske forfatter Georg Orwell.

Socialdemokratiets tankepoliti, tankekontrol, overvågning og disciplinering giver nemlig dystre påmindelser om George Orwells dystopiske fremtidsroman 1984, hvori han introducerer begreberne "Big Brother", "tankepoliti" og "nysprog" i sin beskrivelse af landet Oceanien. De centrale tematikker 
i Orwells roman er overvågning og disciplinering og ikke mindst påvisningen af de katastrofale følger både overvågning og disciplinering har for menneskelige relationer, tillid og samvær. Bogen er med udgangspunkt i det nazistiske Tyskland og det stalinistiske Sovjetunionen en advarsel mod, hvor vi ender (ikke: kan ende), hvis vi ikke reagerer på overvågningen og disciplineringen, når vi konfronteres med den - også i den tidligste udgave, hvor det endnu fremstår mindre belastende. Om end bogen er en fremtidsroman, må dens relevans fx i forhold til ovenstående cases siges at være betydelig. Men også en bekræftelse af, at bogen som advarsel ikke har virket efter sin hensigt. Således er den socialdemokratiske nedskrivning af kursen på demokratiske værdier og demokratisk dialog en trist bekræftelse af den ringe effekt af Orwells advarsel.

Overvågningen disciplinerer menneskene, der indretter og tilpasser deres ageren i forhold til intensiteten af overvågningen/kontrollen eller blot følelsen af i et nærmest benthamsk panoptisk perspektiv at blive overvåget. Da vi ikke ved, hvornår vi bliver overvåget eller af hvem, bliver disciplineringen altomfattende. Og selv om eksempelvis Haugsbøl i forbindelse med ovennævnte artikel understreger, at intet politisk politi skal diktere, hvad hun må sige og ikke sige (Berlingske Tidende, 17. februar 2020), ligger potentielt hos mange frygten for, at udtalelser kan have en effekt på eksempelvis deres arbejdsmæssige og dermed sociale og familiemæssige liv, hvilket sandsynligvis har effekt på de fleste. Hvis denne antagelse er korrekt, bliver det til et spil, hvor rational choice baserede beslutninger afgør ens valg og ikke ønsket om at bidrage til en etisk baseret demokratisk dialog/kritik, som beskrevet af den tyske sociolog Jürgen Habermas i hans bog, Den kommunikative handlen.

Med ovenstående in mente er det også i relation til det beskrevne om det falske selv og identitet tankevækkende, hvordan Socialdemokratiet kobler deres tankepoliti-tilgang og partiets tilgang til demokrati. At det mildest talt ikke er egnet til at vække tillid, dokumenterer den ovenfor beskrevne praksis i relation til de to "cases", når man kobler dem til partiets selvopfattede identitet.

\section{Den demokratiske forpligtelse - nåh den!}

Socialdemokratiet identificerer sig naturligvis som et demokratisk parti, åben for dialog, åben for kritik og respektfuldt med plads til uenigheder, hvilket Leif Lahn Jensen (S) er citeret for i forbindelse med partiets magtudøvelse over for kritikere (Berlingske Tidende, 17. februar 2020). Han udtaler:

Vi politikere skal - ligesom vores medarbejdere - naturligvis være i dialog med aktører som deltager i samfundsdebatten, så vi f.eks. undgår misforståelser og fejltolkninger af vores politik. Vi har alle sammen en interesse i, at der debatteres og diskuteres på et korrekt og oplyst grundlag i den offentlige debat. [...] Den dialog, vi har med 
aktørerne, skal være ordentlig og saglig og foregå med respekt og plads til uenigheder og forskellige opfattelser. Jeg kan ikke genkende, at vi på nogen måde har forsøgt at forhindre en fri og kritisk debat, men beklager selvfølgelig, hvis det er blevet oplevet sådan.

En udmelding karakteriseret ved en tolerance, der tilsyneladende respekterer den demokratiske dialog. Men ikke desto mindre også et eksempel på et beklageligt selvbedrag, der illustrerer misforholdet mellem Socialdemokratiets ønskede identitet og den faktiske identitet (praksis), når henses til blot de to eksemplificerede cases i denne artikel. Dette foldes yderligere ud, hvis man læser partiets principprogram (Fælles om Danmark - Socialdemokratiets Principprogram, vedtaget på Socialdemokratiets Kongres 2017), hvor det under rubrikken Demokrati og dannelse (uden sideangivelse) bl.a. hedder:

DEMOKRATI OG DANNELSE Vi tror på demokratiet. Det er den eneste retfærdige og mest effektive styreform i verden. Et demokrati skal ikke have skel og modsætninger mellem dem, der bestemmer, og dem, der bestemmes over. Ethvert myndigt menneske har ret til at deltage i demokratiet. Ved valgdeltagelse, ved at ytre sig frit og ved at forsamle og organisere sig med andre. På den måde kan man præge rammerne om sit eget liv. Det kræver adgang til klar og tydelig information og mulighed for inddragelse. Danmark skal være et oplysnings- og deltagelsessamfund, der baserer sig på borgernes aktive engagement. Almen dannelse er en nødvendighed og et ideal i et demokrati. Det kræver opdragelse i demokrati fra den tidlige barndom og op gennem hele uddannelsessystemet. Og det fordrer gode muligheder for uddannelse samt et rigt kultur- og foreningsliv (min fremhævelse, JH)

Temmelig misvisende, når henses til både den tilsyneladende møjsommeligt udtænkte plan for at intimidere en potentiel forligspartner og den massive magtanvendelse over for og intimidering af kritiske debattører. Og i alle tilfælde ikke noget, der tjener til at øge endsige blot bevare tilliden til Socialdemokratiet. Og netop spørgsmålet om tillid antager absurde dimensioner, når man inddrager statsminister Mette Frederiksens åbningstale til Folketinget i oktober 2019. Her understreger hun vigtigheden af, at politikerne skal fokusere på tillid og dermed sikre sig befolkningens opbakning, og hendes indledning giver mindelser om tvivlsom science fiction-litteratur. Et karakteristikum, der i øvrigt bekræftes længere henne i talen.:

Barnevognen, som står uden for Brugsen. Vel og mærke med barnet i.

Jordbærboderne i vejkanten. Hvor pengekassen står frit fremme.

Vores børn, der cykler til skole. 
Jeg har det på mange måder ligesom Dan Turèll: Jeg holder af hverdagen.

For det er de små ting, der summer op til vores store historie.

Hverdagen.

Fortid, nutid.

Med et enkelt dansk ord: tillid.

Når man spørger os danskere, om vi har tillid til andre mennesker, så svarer rekordmange: ja.

I Danmark har vi ikke guldminer. Vi har heller ikke haft det, men vi har noget, der er meget mere værdifuldt. Vi har tillid til hinanden.

På tillid har vi bygget et samfund. Med pligter. Og med rettigheder. Men i den rækkefølge.

Jeg betaler min skat i tiltro til, at du betaler din.

Jeg betaler til dit lægebesøg i tiltro til, at du betaler for mit.

Vi har den solidaritet.

Og når vi mødes i boligkvarteret, på arbejdspladsen, til forældremødet, menneske til menneske, så møder vi hinanden med tillid.

Det er ikke bare hyggeligt, det er en kæmpe styrke.

Bare ét eksempel: Hvis en ingeniør på en dansk arbejdsplads har lavet en tegning, som smeden ret hurtigt kan gennemskue ikke holder vand i virkeligheden, så går smeden hen til ingeniøren og siger: Hør, der er lige en detalje dér. Skal den ikke være lidt anderledes?

Det kan kun lade sig gøre, fordi de to kender hinanden. Fordi de spiser madpakken sammen i kantinen. De har måske gået i skole sammen. Og søndag morgen spiller de oldboys football.

Danmark hænger sammen. Der er den tillid, nærhed, gensidige respekt imellem os.

Det giver stabilitet.

Det giver kreativitet.

Det giver arbejdspladser.

Og det giver fremgang.

Tillid gør os ikke kun trygge. Det gør os faktisk også rige.

Danmark er et fantastisk land!

Kan I genkende mit Danmarksbillede?

$[\ldots]$

Skal vi ikke - gamle som nye medlemmer af folketinget - sætte den fælles ambition: at være den allerbedste udgave af Folketinget i det år, vi starter i dag?

For selvom tilliden til os politikere er steget en lille bitte smule, så ligger den jo frygtelig lavt. 
Og jeg ser den manglende troværdighed om alle os som et opråb, vi skal tage meget mere alvorligt.

Jeg tror, den hænger sammen med, at vi nogle gange - hvordan skal jeg sige det - har det med at puste vores resultater lidt for meget op, ikke altid er ærlige over for vores befolkning, lader som om noget, der er svært, er let og omvendt.

Det vil jeg prøve at holde mig fra.

For at blive inden for den religiøse reference, artiklen blev indledt med, drejer det sig her mere om, at ånden er redebon, men kødet er skrøbeligt, når teori og praksis konfronteres.

Socialdemokraterne tror formentlig selv på statsministerens svulstige ord uden at reflektere over endsige inddrage den "besværlige" praksis. Måske bedst karakteriseret ved "livsløgn". "Livsløgn" var det ord, den norske dramatiker Henrik Ibsen brugte og diskuterede i sit ungdomsdrama "Vildanden" (1884). En livsløgn er et selvbedrag, som står centralt i en persons opfattelse af sig selv både personligt og professionelt. Ibsen præsenterer problematikken i sit drama ved at lade doktor Relling sige til selvbedrageren Hjalmar Ekdal: "Tager man livsløgnen fra et gennemsnitsmenneske, så tager man lykken fra ham med det samme". Ibsen advokerer for, at der ingen grund er til at tage livsløgnen fra folk, hvis den ikke har skadelig virkning på omgivelserne. Dette er jo netop en central pointe i relation til den socialdemokratiske livsløgn: den er i al enkelhed skadelig for omgivelserne - og skal afsløres. Som Kierkegaard skriver, vil det falske selv eller selvbedraget altid blive afsløret og vise, at der intet andet findes end tomhed. Og kuriøst bemærker Kierkegaard, at det værste ved selvbedrag er, at man altid har bedrageren hos sig. Hos Kierkegaard handler det i al enkelhed om at være autentisk og ikke-autentisk.

Og dette er måske et altdominerende problem i forhold til Socialdemokratiet: hvem er de? Har de gennemgået en ubevidst metamorfose og gået fra at være en rolle til at spille en rolle i et omfang så ingen (hverken dem selv eller omgivelserne) ved, hvem de længere er. I alle tilfælde et spørgsmål, når man holder deres selvforståelse som formuleret i deres Principprogram op mod den praksis, de eksercerer.

Når (livs)løgnen når et punkt, hvor man ikke længere ved, hvem man interagerer med, foreligger grundlaget for det totale tillids(sammen)brud. Men måske er Frederiksens megen tale om tillid udtryk for en besværgelse - hvem ved, når det er Socialdemokratiet, man interagerer med.

Mette Frederiksen bruger begrebet tillid mere end 30 gange i sin tale uden egentlig at definere begrebet. Hun holder sig til eksempler: en kommunikativ ganske smart tilgang, men ikke særlig valid i forhold til at synliggøre, hvordan begrebet defineres. Igen er det som i relation til deres noget 
uklare identitet vanskeligt at se, hvad tillid betyder i alle tilfælde i en socialdemokratisk fortolkning af begrebet. Nedenfor skal begrebet derfor foldes ud.

\section{Tillid}

Bordum og Wenneberg (red.) har i deres bog Det handler om tillid (2001) behandlet fænomenet tillid. Ifølge bogen er tillid bl.a. karakteriseret ved følgende:

Tillid og troværdighed er uløseligt knyttet til hinanden, og tillid betragtes ofte som den mest grundlæggende sociale mekanisme, som i vid udstrækning holder sammen på ikke blot personlige relationer, men også på hele samfundet. Sammenhængen mellem troværdighed og tillid er, at troværdighed er en forudsætning for, at vi kan etablere tillid til både skriftlig og/eller mundtlig kommunikation - et forhold hverken Mette Frederiksen eller partiets drabanter i deres forsøg på at gøre kritikere tavse åbenlyst ikke har forstået, når de forsøger at erstatte tillid med magt. Troværdighed kommer ligesom tillid ikke af sig selv. Troværdighed er ganske enkelt ikke noget, man har, men noget man opnår eller gør sig fortjent til.

Troværdighed skabes ved hjælp af selvfremstilling eller nærmere bestemt ved, at en afsender i sin selvfremstilling sandsynliggør, at vedkommende lever op til de værdier, som vedkommende hævder at stå inde for. Et forhold, der åbenlyst ikke fylder meget i en socialdemokratisk bevidsthed, eller som partiet måske blot ignorerer. Selvfremstilling er en kontinuerlig proces både i relation til personer og organisationer, når man tilstræber at kommunikere et konsistent billede af sig selv (læs: sit selv), der skal kunne opnå social gyldighed.

Tillid er rettet mod fremtidig adfærd og er karakteriseret ved usikkerhed om en andens handlinger. Netop usikkerhed og fremtidig adfærd indebærer, at tillid er placeret på en akse mellem viden og ikke-viden, hvilket implicerer, at tillid kan defineres som det at tro på nogen eller noget til trods for usikkerhed. Og netop i relation til manglende viden er tillid central i forhold til at sikre social interaktion. Tillid opbygges over tid, hvilket indebærer, at der skal mange situationer til for at bekræfte tilliden. Mistillid derimod kan udløses på baggrund af en enkelt handling eller et enkelt udsagn, der strider mod forventninger til en bestemt handleform, fx de to her behandlede cases.

Selvfremstilling er altså et udtryk for en persons eller en organisations officielle selvforståelse.

Tillid testes på adfærd, og hvis man vil fremstå som troværdig - og derved være værdig til at opnå tillid - så skal selvfremstillingen være af en sådan karakter, at modtager føler sig forsikret om, at adfærden ikke blot er strategisk, men er baseret på ægte overbevisning, hvilket også implicerer et etisk perspektiv (jf. afsnit 4.2). 


\section{Etik}

Etiske overvejelser har som oftest deres udspring i en række centrale fænomener som godt og ondt, retfærdigt og uretfærdigt, rigtigt og forkert, dyder og laster, normer og værdier, pligt og ansvar, skyld og skam, og fordømmelse og tilgivelse.

Generelt opererer man med dydsetik, pligtetik, konsekvensetik, for ikke at forglemme Løgstrups etiske fordring, der eksplicit inddrager tillid i sine overvejelser.

Dydsetik som formuleret af Aristoteles beskæftiger sig med den gode handling. Argumentet er, at enhver god handling kan relateres til ethvert dydigt menneske. Med dydig menes der, at man følger den "gyldne middelvej"/dyden, dvs. at man hverken underkaster sig sine bevæggrunde for meget eller for lidt (fx at man hverken er fej eller dumdristig).

Pligtetik eller deontologisk etik er den etiske form, hvor man kigger på, om handlingen er i overensstemmelse med den gældende pligt eller bagvedliggende regel. Ifølge Kant er en god/rigtig handling defineret som en handling, der udelukkende er udført af pligt.

Konsekvensetik eller teleologisk etik beskæftiger sig med, om de konsekvenser, en handling får, er gode eller dårlige for den største gruppe af mennesker. Kun ved at se på konsekvenserne af en handling kan man vurdere om den er god/rigtig eller dårlig/forkert. Af denne grund (at man ser på konsekvenserne af handlinger) kan man med denne etiske form "beregne" plusser og minusser i konsekvenserne, men man kan først være sikker på sit resultat, når handlingen er udført (utilitarisme).

Uanset hvilken etik, man anskuer forskellige situationer ud fra, handler det om værdier, og hvordan man rangerer dem i et givet fællesskab, jf. eksempelvis tillid, mistillid og løgn i vores vestlige fællesskab. Et fællesskab defineres ved en sammenhængende og fælles opfattelse af værdier, holdninger, normer og adfærd. Med udgangspunkt i en lidt populær forklaring, der siger, at moral er praktiseret etik, bliver etik udgangspunkt for retningslinjer for passende og upassende adfærd og et udtryk for en velovervejet respekt og agtelse for fællesskabets værdier og normer. Etik betinger $\mathrm{dog}$, at der er tale om intentionelle handlinger, da etik og moral mister deres retningsgivende status og legitimitet, hvis handlinger blot er impulsive og/eller tilfældige. Hvis dette er tilfældet, kan man næppe tale om en etisk forpligtelse. Alene af den grund kan man uden tøven karakterisere Socialdemokratiet for uetisk, når henses til det minutiøst planlagte angreb på Venstre.

Uanset uenigheder om hvad etikkens rolle er, er der bred enighed om, at etik er en levelære, som indeholder de principper, man skal leve sit liv efter. altså en lære om hvilke principper, man bør efterleve i sit liv. I et socialt fællesskab lever vi således i et relationsforhold til/med hinanden, hvor 
vores handlinger løbende involverer og influerer andre. Dette forpligter i et både relationelt og etisk perspektiv, eller som Løgstrup formulerer det i Den etiske fordring:

Den enkelte har aldrig med et andet menneske at gøre uden at han holder noget af dets liv i sin hånd. Det kan være meget lidt, en forbigående stemning, en oplagthed, man får til at visne, eller som man vækker, en lede man uddyber eller hæver. Men det kan også være forfærdende meget, så det simpelthen står til den enkelte, om den andens liv lykkes eller ej.

Det er etikkens opgave at formulere principper, der kan regulere de relationelle (af)hængighedsforhold, så det gode liv fremmes. Eller kort sagt, formulere leveregler for individets handlen i forholdet til dets medmennesker.

Løgstrup siger videre, at i mødet med den anden eller andre bliver vi altid stillet over for etiske valg, der alle har konsekvenser:

Med vores blotte holdning til hinanden er vi med til at give hinandens verden dens skikkelse. Hvilken vidde og farve den andens verden får - for ham selv er jeg med til at bestemme med mine holdninger til ham. Jeg er med til at gøre den vid eller snæver, lys eller mørk, mangfoldig eller kedelig - og ikke mindst er jeg med til at gøre den truende eller tryg. Ikke ved teorier eller anskuelser, men ved blotte min holdning. Hvorfor der er en uudtalt, så at sige anonym fordring til os om at tage bare på det liv, som tilliden lægger i vores hånd. (Den etiske fordring)

I Løgstrups forståelse er etik universel, men et universelt perspektiv, der understreger det enkelte menneskes værdi. I sin argumentation fremhæver Løgstrup, at der eksisterer mindst tre grundlæggende elementer, når man taler om etik i relationelle sammenhænge: tillid, kærlighed og talens åbenhed (suveræne livsytringer), som ifølge Løgstrup er forudsætninger for at mennesker kan forholde sig til hinanden, og som basalt set er grundlaget for etiske normer. Tillid står især skarpt hos Løgstrup, da tillid indebærer, at vi giver noget af os selv og som beskrevet ovenfor, at modtager føler sig forsikret om, at adfærden ikke blot er strategisk, men er baseret på ægte overbevisning.

Hvis antagelsen om, at tillid er det, der binder vores samfund sammen, skal det måske understreges, at manglen på tillid indebærer en risiko for fragmentering af samfundet. Med en fragmentering gives der også potentielt rum til at diverse ekstreme bevægelser kan udvikle sig, så måske kunne man ønske, at Løgstrups Den etiske fordring blev obligatorisk pensum for Socialdemokratiet i almindelighed og for formanden i særdeleshed. 


\section{Corporate Communication}

Socialdemokratiet er en organisation, og det blev ovenfor nævnt, at en persons/organisations selvfremstilling skal være karakteriseret ved, at en modtager føler sig sikker på, at en given adfærd ikke blot er strategisk, men er baseret på ægte overbevisning.

Begge dele mislykkes for både partiet og formanden - endog i udtalt grad. Og hvis man anskuer en socialdemokratisk praksis i forhold til det intenderede selvbillede i et organisationskommunikativt perspektiv, understreges og bekræftes utroværdigheden yderligere, når henses til identitet, falsk selv, autenti-ikke-autenti etc.

Arbejdet med værdier, identitet og image tjener til at profilere en organisation såvel eksternt som internt. Den klassiske opsplitning mellem intern og ekstern profilering - hvor man fx kommunikerede på én måde internt til medarbejderne og på en helt anden måde eksternt til offentligheden - er ikke længere det dominerende paradigme.

Dermed bliver alle medarbejdere og ikke kun de faglig relevante enheder ansvarlige for og "medejere" af organisationens kommunikation. Medarbejderne skal kunne kommunikere på vegne af organisationen, og de skal vide, hvad organisationen er og står for. Og dette gøres ikke ved en eller anden mere eller mindre tilfældigt sammenstykket kommunikationsplan, men alligevel kunne det måske være baggrunden for angrebsplanens punkter om læsemøder og håndholdt info (?). Med alle medarbejderne som kommunikatører er det derfor helt afgørende, at ledelsen i en organisation sikrer sig, at de forståelser, som organisationen kan identificere som sine, også er dem, medarbejderne kommunikerer.

Det forhold, at medarbejderne skal vide, hvad organisationen er og står for, betyder også, at det i højere grad end tidligere (bevidst) er identitet og værdier, der kommunikeres fra organisationer. I dag er det således, at stort set ingen organisationer fremstiller noget, der ikke kan efterlignes eller kopieres. Hvad der til gengæld ikke kan kopieres eller efterlignes er - uanset hvor meget man forsøger - identiteten og værdierne i en organisation. Dette udgør naturligvis et problem, hvis man ikke ved, hvem man er, da man så ikke kan kommunikere sin identitet eller måske kun den falske eller inautentiske identitet, hvis man selv kan skelne de to fra hinanden længere. Og dermed kommer det til også at handle om tillid.

Om ovenstående er baggrunden/årsagen til, at socialdemokratiske embedsmænd forsøger at erobre diskursen ved at true/intimidere forskellige kritikere/kommentatorer af partiets politik, skal være usagt. Men ikke desto mindre er det ihukommende navnene på den planlagte aktion i forbindelse 
med Udligningsreformen åbenbart en accepteret måde at angribe diverse kritikere på for at få dem til at makke ret og disciplinere sig efter de socialdemokratiske ønsker (læs: viljer). Måske forsøger de at skjule deres manglende kapacitet, integritet og deres falske selv bag diskursiv magt?

At fortælle hvem virksomheden er, og hvilke værdier den har, er derfor en af de vigtigste interne og eksterne opgaver ledelsen i en organisation har - også i forhold til at skabe og vedligeholde tillid.

\section{E. Hvad er diskurs?}

Der er mange forskellige tilgange til og varierende definitioner af diskurs. I denne artikel er det Foucaults arbejder, der er i fokus. Hos Foucault udgør diskursen en indbyrdes forbunden kæde af udsagn, som samlet repræsenterer en videnform. Diskurserne definerer, hvilken viden, der er "rigtig" og hvilken viden, der er "forkert", hvad der kan tales om og ikke tales om, samt hvilken betydning, det kan tillægges inden for en given diskurs.

Diskurser repræsenterer altså en form for afgrænsede mulighedsbetingelser, idet kun de muligheder, diskurserne tilbyder, er praktisable. Man må således acceptere diskurserne og videnmagten, hvis man vil være en indlejret del af et diskursivt fællesskab som de socialdemokratiske forsøg på at disciplinere både Haugbølle og Per Nikolaj Bukh er et eksempel på. Eller i modsat fald opleve at blive ekskluderet fra et givet (diskurs)fællesskab, fx via sanktioner som Roger Buch italesætter, når han taler om det problematiske i, at et parti eller en regering kontakter kritikere, da personer og/eller organisationer begynder at være bekymrede for konsekvensen, hvis de er kritiske over for magthaverne.

I Les Mot et les Choses redegør Foucault for erkendelsesteoriens udvikling i perspektiv af og i relationen til historien, som determinerer og betinger tænkningen. Epistemet er ifølge Foucault et sprogsystem i et samfund, som er udgjort af diskurserne. Diskursen bliver således den accepterede sandhed indenfor et system in casu sandheden, som Socialdemokratiet definerer den. At den er accepteret, betyder også, at der ingen absolut sandhed findes, også selv om sandheden forekommer givet. Sprogsystemet lukker sig så at sige om sig selv, og der eksisterer ikke nogen overordnet struktur, hvorfor mening må tolkes i dens forhold til den givne struktur. Det er således epistemet, der betinger og muliggør tænkning, kultur og virkelighed.

Magt og viden er tæt forbundne hos Foucault, der selv anvender udtrykket 'magtviden', som understreger sammenhængen mellem (den vedtagne) sandhed og magt, ligesom det fokuserer på, hvem der har definitionsmagten, i forhold til hvad sandhed er, hvordan den udtrykkes, og ikke 
mindst, fra hvilken position den italesættes. Positionen er i relation til de aktuelle cases en magtposition, hvorfra Socialdemokratiet via deres embedsværk forsøger at definere sandheden, og hvordan de ønsker, den skal italesættes.

Hos Foucault bliver mennesket et resultat af den etablerede diskursive magt, og det er i højere grad et spørgsmål for individet at opfinde sig selv, eller med andre ord blive det, man gør sig til. Og spørgsmålet om at (op)finde sig selv er jo i alle tilfælde problematisk i et eksistentialistisk perspektiv som beskrevet af både Kierkegaard og Sartre, hvor det jo i højere grad handler om at vælge sig selv og vare sin rolle (det ægte selv i modsætning til det falske selv). I denne artikel argumenteres der for, at valget i et eksistentialistisk perspektiv er på vej til at blive suspenderet, da de etablerede diskurser så at sige træffer valget for det enkelte individ, hvorfor det ikke længere bliver et spørgsmål om at vælge det ægte selv/det autentiske, men i højere grad om at forholde sig til og vælge, hvilket (falsk) selv, vi ønsker at fremstille, og hvilken rolle vi ønsker at spille.

Foucault suppleres i relation til sin analyse af magt og viden og (anti)demokratiet - eller måske snarere demokratur - i høj grad af Habermas, der i sine sociologiske og kommunikative analyser af det borgerlige samfund (Den borgerlige offentlighed) afdækker, hvordan demokratiet og mulighederne for en etisk diskurs langsomt, men sikkert eroderes, og som sådan potentielt baner vej for andre styre-/magtformer.

\section{F. Habermas diskursetik og Hannah Arendt}

Habermas har i sit forfatterskab i overvejende grad bidraget med en ideologikritik af vores samfund og været en af de helt centrale bidragsydere i forsvaret for demokrati og demokratisk dialog.

I sin afhandling, Borgerlig offentlighed (1962), opererer han med en struktur for den borgerlige selvforståelse i et kontrastivt perspektiv. Det borgerlige samfund er konstitueret ved henholdsvis Stat og Samfund, hvor han opdeler Samfund i en offentlig og en privat del, som for den private dels vedkommende yderligere opdeles i en intimsfære og en socialsfære. Intimsfæren er som betegnelsen angiver vores private domæne, mens socialsfæren fx omfatter vores relation til arbejdsmarkedet. 


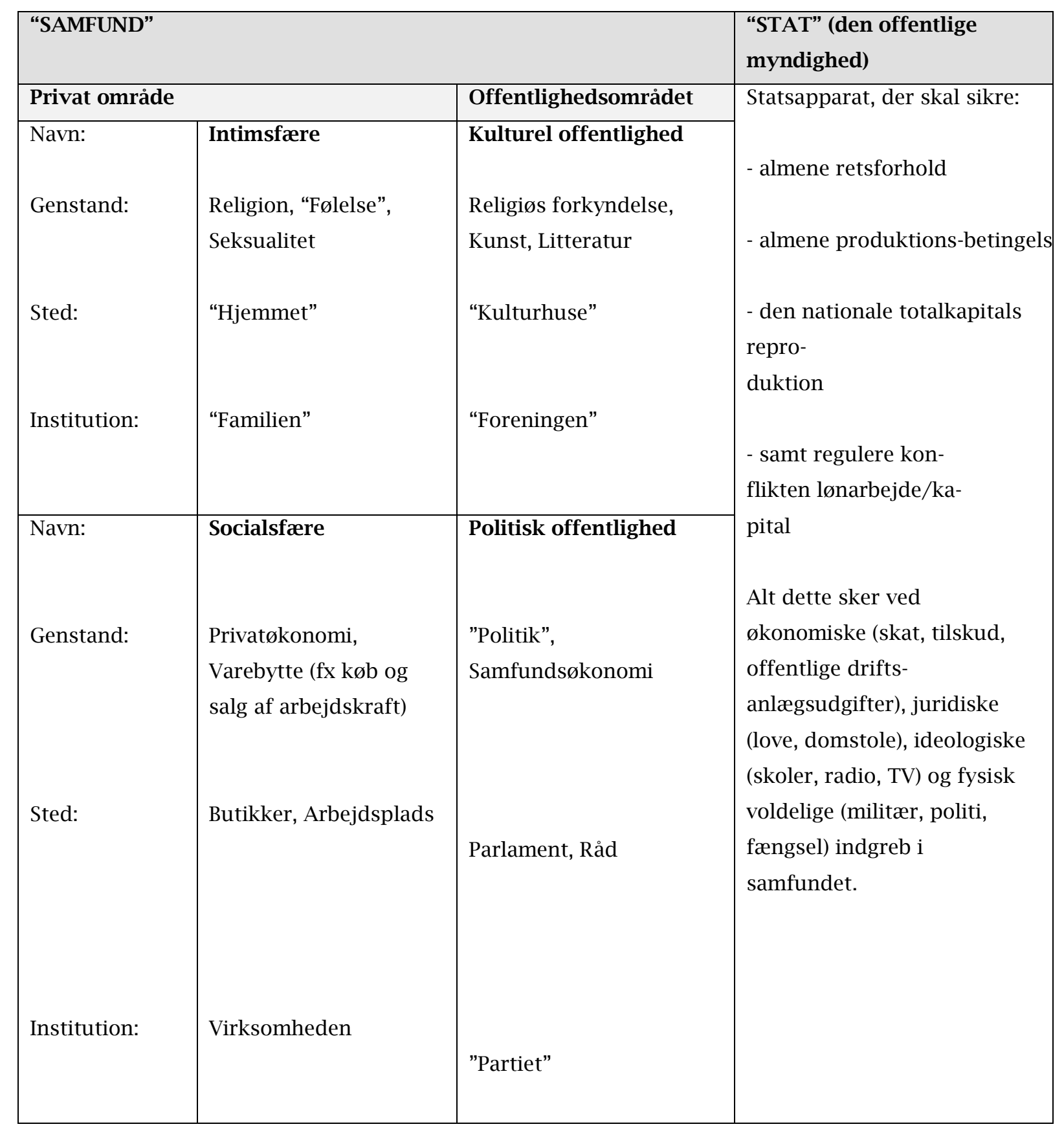

Kommunikation i den borgerlige offentlighed var ideelt set fordoms- og herredømmefri ogkarakteriseret af rationalitet. Det betød, at det var argumenternes styrke, der var afgørende for udfaldet af en meningsudveksling og dermed det grundlag, borgerne havde for at give staten myndighed til at udøve magt over forhold, der var forankret i henholdsvis intimsfæren og socialsfæren.

Samfundet udviklede sig dog ikke som et borgersamfund, men udviklede sig i stedet til et 
kapitalistisk klassesamfund. I forlængelse af og som en konsekvens af klasseopdelingen i samfundet blev det tydeligt, at idealet om den fordoms- og herredømmefri diskussion ('kommunikativ handlen') ikke længere kunne realiseres. Efterhånden bevægede staten sig gradvist ind i den private sfære med love og reguleringer, og samtidig overtog private organisationer dele af statens opgaver. Skillelinjerne mellem borgerlig offentlighed og stat blev uklare og medførte/medfører større uigennemskuelighed og magtforskydninger.

En skillelinje, Socialdemokratiet med sine i forhold til demokratiet kritiske handlinger er med til at udviske og sløre. Spørgsmålet er nemlig i relation til demokratiets understregning af individuelle rettigheder, om partiet i sine bestræbelser på dels at monopolisere definitionsmagten omkring, hvad "den rigtige viden" (læs: socialdemokratisk) er, og hvordan den skal ekserceres, negligerer og ekskluderer dialogen mellem frie individer for at nå sine mål og på den måde tilføjer den demokratiske/politiske dialog en yderligere og nok så alvorlig dimension, nemlig truslen om at suspendere den demokratiske dialog og dermed tilsidesætte rettigheder for det enkelte individ og dermed muligheden for på baggrund af rationalitet og argumenters styrke at nå en (to-vejssymmetrisk) konsensus.

Svaret på dette misforhold er ifølge Habermas en diskursetik, der anerkender den fordoms- og herredømmefri diskussion, hvilket kan bidrage til at aktivere en demokratisk dialog - i modsætning til hvad Socialdemokratiet har præsteret i relation til de to omtalte cases i denne artikel. Socialdemokratiet har udelukkende praktiseret det Habermas karakteriserer som 'strategisk handlen' (i modsætning til 'kommunikativ handlen'), der betyder, at en (sprog)handling udføres for at opnå et prædefineret bestemt mål, fx at disciplinere eventuelle kritikkere til at forstå og anerkende "Den rigtige viden". Strategisk handlen indvirker på andres intentioner og handlinger og har til formål at opnå en bestemt effekt på modtageren.

Diskursetik kan summarisk i forhold til Habermas meget detaljerede argumentation refereres som følger.

Habermas definerer en diskurs som en refleksiv dialog om en påstands gyldighed, som man forsøger at skabe rationel konsensus om på baggrund af holdbare argumenter. I forhold til diskursen er der en række spilleregler, som man må følge. Disse spilleregler er indlejret i formalpragmatikken, som foreskriver en række betingelser, der skal være opfyldt, før vi kan være sikre på, at den konsensus, der er skabt, er rationelt funderet. Diskursen beskæftiger sig med propositioner, som er påstande eller udsagn, som indeholder et problematiseret gyldighedskrav. Diskursens udgangspunkt er, at mindst en deltager i diskursen/dialogen markerer uenighed i forhold til et udsagns gyldighed. Og dette testes så i forhold til gyldighed. Diskursen italesættes i forhold til det bedre argument og afsluttes, når der er etableret rationel konsensus: når alle parter er sikre på, at de mener det samme 
med en påstand, har opnået enighed i forhold til påstanden og anerkender samme begrundelser for enigheden. Habermas understreger, at det ikke er personer, der afslutter diskursen. Det gør til gengæld den rationelt velbegrundede konsensus. Hvis samtalen afbrydes eller en af samtalepartnerne udskifter den kommunikative handlen med strategisk handlen ophæves diskursen og forsøget på at opnå konsensus sker ikke længere. I stedet kommer det til at dreje sig om at opnå et prædefineret bestemt mål.

Habermas argumenterer for, at kommunikativ handlen har realpolitisk relevans i forhold til demokratiet, idet han argumenterer for, politiske diskurser kan kvalificeres gennem en diskursetisk/kommunikativ handlen.

Om Socialdemokratiet nogensinde har hørt om den kommunikative handlen eller diskursetik, skal her være usagt. Men næppe, når man betragter deres utroligt kluntede forsøg på at kolonisere og disciplinere forskellige aktører i samfundsdebatten gennem diskursiv tvang og ekskluderende magtudøvelse. Og deres interesse for demokratisk dialog synes også rimelig overskuelig.

I forhold til den demokratiske dialog er det naturligvis også relevant at inddrage en af de bedst argumenterede analyser af demonteringen af den demokratiske dialog, nemlig Hannah Arendts The Origins of Totalitarianism (1958), hvor Arendt analyserer, hvordan en fællesmenneskelig verden eroderes ved at eliminere menneskelige relationer. Hun argumenterer for, at elimineringen foregår gradvist og derfor "usynligt". I første fase elimineres den politiske relation, i anden fase de etiske relationer og moralnormer. I tredje og sidste fase nedbrydes relationerne mellem mennesker som frie mennesker, der i dialog med andre kan kommunikere deres individualitet. I dette individualiserede og dehumaniserede ørkenlandskab er mennesket overladt til sig selv og til at forsøge at skabe en identitet - også en opgave for Socialdemokratiet. Men for partiet også et tveægget sværd, hvor de uvidende om, hvem de selv er, bliver nødt til at finde sig selv - ikke genopfinde, da der lige pt. intet andet er end falskheden, tomheden og selvbedraget 


\section{Referencer}

Arendt, Hannah (1958): The Origins of Totalitarism (Meridian Book, The World Publishing Company)

Berlingske Tidende 17. februar 2020

Berlingske Tidende 23. februar 2020

Berlingske Tidende 24. februar 2020

Bordum, Anders \& Søren Barlebo Wenneberg (2001): Det handler om tillid (Samfundslitteratur)

Det gamle Testamente (Bibelskabet.dk)

Foucault, Michel (1966): Les mots et les choses (Collection Bibliothèque des Sciences humaines, Gallimard) https://doi.org/10.1522/24902275

Foucault; Michel (2002): Overvågning og straf (Det lille forlag)

Foucault, Michel (2003): Ordene og tingene (Gyldendal)

Fælles om Danmark - Socialdemokratiets Principprogram, vedtaget på Socialdemokratiets Kongres 2017)

Habermas. Jürgen (1962/1975): Borgerlig offentlighed (Fremad)

Habermas, Jürgen (1981): Den kommunikative handlen (Aalborg Universitetsforlag) https://doi.org/10.7146/politica.v28i4.68079

Ibsen, Henrik (1884); Vildanden

Jyllands Posten 23. februar 2020

Løgstrup, K. E. (2010): Den etiske fordring (KLIM)

Orwell, Georg (1949/2016): 1984 (Gyldendal)

Statsministerens Åbningstale, oktober 2019

Søren Kierkegaards Skrifter v/ Søren Kierkegaard Selskabet (SKS)

https://doi.org/10.1515/9783110243987.427

van Riel, Cees B. M. (1995): Principles of Corporate Communication. London: Prentice Hall. 